\title{
International Law in a Kaleidoscopic World
}

Edith Brown Weiss

Georgetown University Law Center, weiss@law.georgetown.edu

This paper can be downloaded free of charge from:

https://scholarship.law.georgetown.edu/facpub/1622

http://ssrn.com/abstract=2734392

1 Asian J. Intl. L. 21-32 (2011)

This open-access article is brought to you by the Georgetown Law Library. Posted with permission of the author. Follow this and additional works at: https://scholarship.law.georgetown.edu/facpub

Part of the International Law Commons 


\title{
International Law in a Kaleidoscopic World
}

\author{
Edith BROWN WEISS* \\ Georgetown University, United States of America \\ weiss@law.georgetown.edu
}

International law is developed and implemented today in a complicated, diverse, and changing context. Globalization and integration, fragmentation and decentralization, and bottom-up empowerment are arising simultaneously among highly diverse peoples and civilizations. Most importantly, this period is characterized by rapid and often unforeseen changes with widespread effects. Advances in information technology make possible ever shifting ad hoc coalitions and informal groups and a myriad of individual initiatives.

The resulting kaleidoscopic world faces global problems that affect everyone: climate change, financial crises, health threats, communication disruptions and cyber attacks, ethnic and other conflicts, among many others. These cannot be managed solely by one state or a handful of states, or solely by non-state actors. Some of these problems erupt quickly and are not easily contained. Others, like climate change, have inherently long time-horizons and affect the welfare of future generations. One of the most pressing problems is poverty, with more than I.4 billion people existing on less than US\$I.25 per day in 2008 and another I.2 billion people on less than US\$2.00 per day. ${ }^{\mathrm{I}}$

This kaleidoscopic world both offers opportunities for international law to become more relevant and central and poses significant dangers for its relevance and effectiveness. This article provides an initial analysis of the significance of the kaleidoscopic world for international law.

\section{GLOBAL CROSS CURRENTS}

While states continue to be central actors in international law, there are now many other actors and important systemic developments. There are three fundamental elements that shape the evolution of international law today: globalization and integration; fragmentation and decentralization; and bottom-up empowerment arising among highly diverse peoples and civilizations, in a context of rapid change.

\footnotetext{
* Francis Cabell Brown Professor of International Law, Georgetown University Law Center, USA; former President, American Society of International Law. This article is based on the author's presentation at the Second Biennial General Conference of the Asian Society of International Law, Tokyo, Japan, I August 2009.

I. World Development Indicators 2008: Poverty Data Supplement (2008), online: World Bank 〈http:// siteresources.worldbank.org/DATASTATISTICS/Resources/WDIo8supplement I 2 I 6.pdf $>$.
} 


\section{A. Globalization and Integration}

The first element, globalization and integration, is reflected in the rapid growth of international institutions, including government and non-governmental organizations, private sector networks, and other transnational groups, including religious, ethnic, familial, and illicit ones. The 2008-2009 Yearbook of International Organizations [Yearbook] reported 2,I66 international intergovernmental organizations and dependent bodies, II,990 international non-governmental organizations with 4,738 dependent bodies, 2,379 organizations associated with multilateral treaty and bilateral agreements, 726 autonomous conference series, and 6,670 internationally oriented national non-governmental organizations. ${ }^{2}$ According to the Yearbook, the total number of international organizations approaches nearly 30,000. Another 30,000 are listed as inactive or unconfirmed. ${ }^{3}$ These numbers attest to growing globalization and integration in the international community.

Markets are also increasingly globalized. Within developing countries, cellphones are reducing dependence on middlemen to arrange market transactions in agricultural products such as coffee. Many corporations produce globally, with management, materials, components, and production located in different countries. Institutions in industrialized countries increasingly outsource services to companies or firms in other countries.

\section{B. Fragmentation and Decentralization}

At the same time as globalization and integration are increasing, there is increased fragmentation within states and pressures for decentralized decision-making. Ethnicity and the need for personal affiliations and satisfaction push towards decentralization and fragmentation. The strong sense of community that bound many citizens to their states does not extend to transnational groups associated with integration and globalization. Ethnic, religious, familial, and other entities often have stronger links to similar groups in other states than to their own governments. ${ }^{4}$

These developments challenge the power of states as well as the effectiveness of transnational actors and international institutions. They affect the implementation of international law and compliance with it. On the one hand, decentralization can ensure that local people have a voice in designing and implementing legal arrangements that affect them and thus can enhance compliance with legal norms. On the other hand, it can militate against compliance with norms that are seen as irrelevant or that run counter to other priorities.

\section{Bottom-up Empowerment}

Simultaneously with growing integration and fragmentation, the international system is witnessing bottom-up empowerment, with innumerable ad hoc coalitions, associations,

2. Union of International Associations, Yearbook of International Organizations 2008-2009, vol. 3 (Munich: KG Saur Verlag, 2008) at I6I8.

3. Ibid.

4. Edith BROWN WEISS, "The Rise or Fall of International Law" (2000) 69 Fordham Law Review 345. 
communities, and individuals playing important and constantly changing roles. The number of individuals in the world continues to grow. In 2007, the global population was 6.6 billion people and was projected to rise to 9.3 billion by 2050 , with most of the increase in East Asia and South Asia. ${ }^{5}$

Information technology facilitates the rise in the power of communities, ad hoc coalitions and associations, and individuals. Local, national, regional, and global coalitions can form instantaneously on the Internet, and can dissolve as quickly. Many advocacy campaigns now take place on Internet sites that let people collaborate across time and place, for example Facebook, YouTube, Twitter, and various blogs. Mobile phones have become important in organizing coalitions. Some of these campaigns translate into direct action, including the "Pink Chaddi" campaign in Bangalore, ${ }^{6}$ which was started on Facebook, the high-profile protests in London against alleged indiscriminate shelling of Tamil civilians in Sri Lanka, ${ }^{7}$ which started via Facebook and mobile texting, and the Internet campaign for equal pay in the United States. ${ }^{8}$

Changes in technology are equally kaleidoscopic. Blogs have become important means for communicating ideas and influencing others. As of December 2007, the blog search engine "Technorati" tracked more than I I 2 million blogs. ${ }^{9}$ Generally, there is no bar to an individual creating a blog that can be read all over the world. Twitter has reportedly grown by about 350 percent over the last year. ${ }^{\circ}$ As of May 2009, the number of unique users of Twitter was reported to be 19.7 million. ${ }^{\text {I }}$ During the 2008 attacks in Mumbai, eyewitnesses reportedly sent eighty tweets every five seconds as the tragedy unfolded. ${ }^{12}$

While many people do not yet have access to communications technology, the rate of access is increasing rapidly, which means that the influence of individuals and groups (both formal and informal) on the development, interpretation, and implementation of international law is likely to increase. This may be characterized

5. Population Reference Bureau, 2007 World Population Data Sheet (August 2007), online: Population Reference Bureau 〈http://www.prb.org/Publications/Datasheets/2007/2007 WorldPopulationDataSheet. aspx $>$, at 7-9.

6. "Pink Chaddis Still Keep Coming In" The Times of India ( $\mathrm{I}_{3}$ February 2009).

7. Luke BAKER, “Tamils Block London to Protest Sri Lanka” Reuters (20 April 2009).

8. See 42 U.S.C. $§ 2000 e-5$. See generally National Committee on Pay Equity, Equal Pay Day, online: National Committee on Pay Equity 〈http:/www.pay-equity.org/day.html 〉; Organizing for America, The Impact of the Obama Economic Plan For America's Working Women, online: Women for Obama $\langle$ http://my.barackobama.com/page/content/womenissues 〉; AFL-CIO, It's Time for Working Women to Earn Equal Pay, online: AFL-CIO 〈http://www.aflcio.org/issues/jobseconomy/women/equalpay/ .

9. Anne HELMOND, "How Many Blogs Are There? Is Someone Still Counting?" The Blog Herald (I I February 2008), online: The Blog Herald 〈http://www.blogherald.com/2008/o2/I I/how-many-blogsare-there-is-someone-still-counting/ $>$.

Iо. Paul KOCH, "Supposedly Dismal Twitter Statistics Actually Indicate Strength" Viget Engage (I 8 June 2009), online: Viget Engage 〈http://www.viget.com/engage/supposedly-dismal-twitter-statisticsactually-indicate-strength $>$.

II. Ibid.

I2. “Twitter Provided a Vital Link in Mumbai Terrorist Attacks" Impact Lab (28 November 2008), online: Impact Lab 〈http://www.impactlab.com/2008/I I/28/twitter-provided-a-vital-link-in-mumbai-terroristattacks/ $>$. 
as "bottom-up empowerment". Importantly, this development is characterized by constantly changing actors and issues.

This stage in the evolution of the international system, with its emerging bottom-up empowerment, may be characterized as kaleidoscopic. It is informal, and the actors and coalitions constantly change.

These developments both pose challenges for the international legal system and provide opportunities to strengthen and expand the foundations of international law. International law must operate in a new, multilayered system, consisting of states, international institutions, private sector and non-governmental organization networks, the wide range of formal transnational bodies referenced earlier, and the new kaleidoscopic pattern of informal coalitions and individual initiatives.

\section{IMPLICATIONS FOR INTERNATIONAL LAW}

What are the implications of this international context for the development and implementation of international law?

\section{A. Legitimacy}

Foremost, in the emerging kaleidoscopic world, international law will need to be viewed as legitimate by the many layers of actors in the international system and to reflect common values that are resilient to rapid changes and can evolve in concert with fundamental changes.

Onuma Yasuaki has offered a context for addressing this need in his concept of trans-civilizational law. He has distinguished three stages in the evolution of international law-international, transnational, and trans-civilizational law-and argues that we are entering a century of trans-civilizational law. ${ }^{13}$ Trans-civilizational law is intended to provide "a cognitive and evaluative framework based on the recognition of plurality of civilizations". ${ }^{\mathrm{I} 4} \mathrm{He}$ observes that, in considering problems in international law, we must "seek to make explicit cultural and/or civilizational assumptions of ourselves and other actors, and to see and evaluate them by taking these factors into consideration, not regarding those factors as unchangeable, monolithic entities but as changeable, functional variants". ${ }^{15}$ This concept of transcivilizational law is significant for the emerging international system. The diversity and complexity of civilizations and their changeable character and role add to the kaleidoscopic nature of today's world.

International law must be viewed as legitimate both by those who create and implement it and by those whom it affects. Legitimacy includes both the process by which international norms are created and the acceptance of these norms. Failure to

I3. ONUMA Yasuaki, “A Trans-Civilizational Perspective of International Law: Lectures in Public International Law at the Hague Academy of International Law", Lecture Readings (30 July-3 August 2007), online: Peace Palace Library 〈http://www.ppl.nl/summercourses/readinglist.php?year=2007\&lecturer= onuma\&maintopic $=$ Public $\%$ 2oInternational $\%$ 2oLaw $\rangle$.

I4. Ibid., chapter I, section $3(\mathrm{I})$.

I5. Ibid. 
respect these norms may degrade their legitimacy, even if they were viewed as legitimate at the time they came into being. ${ }^{16}$

Equity is an important element of legitimacy. This poses complex issues, both in the historical context and today. How do we define equity? Does it refer to the processes by which international law is created, the substance of the norms, or the outcomes from the interpretation and application of the norms? To whom must the norms be perceived as equitable? What role does perception have in both the definition and implementation of equity? In the multilayered and kaleidoscopic international system that characterizes the twenty-first century, the perception as well as the fact of equity will be important to the legitimacy of international law.

One of the fundamental equity issues stems from the history of the development of international law. Modern international law is usually viewed as having emerged from the Westphalian legal order. ${ }^{17}$ People in countries that achieved independence from colonialism note that they have inherited an international legal system that is European in origin, in whose formation they did not participate, and that does not reflect cultures and traditions across the world. ${ }^{18}$ This concern about the equity of the international legal system needs to be addressed if international law is to serve as a unifying force in a kaleidoscopic world.

In order to foster co-operation and stability, international law needs to reflect values commonly held and to provide processes for decision-making and dispute resolution that all peoples regard as equitable. These are essential whether one characterizes the evolution of international law as adding a trans-civilizational level, or as adding a "bottom-up level" of communities and individuals from disparate cultural and social backgrounds as increasingly important actors in the international system, or as both.

Political theory indicates that viable communities need to share values, whether these communities are global, regional, or local. ${ }^{\text {s9 }}$ They need to believe that they are linked in common understandings. The global communities, the fragmented communities, and the shifting informal coalitions and multitudinous individuals need to share values, which can be reflected in international, as well as transnational and local, law. This is not easy. Even if consensus is achieved on certain universal values, the consensus can break down.

\section{B. Emerging Norms as Contributing to Legitimacy}

In the kaleidoscopic world, legitimacy may also reflect norms of accountability, transparency, participation, and access to dispute settlement and grievance procedures.

I6. See Thomas M. FRANCK, The Power of Legitimacy Among Nations (Oxford: Oxford University Press, I990); Nienke GROSSMAN, "Legitimacy and International Adjudicative Bodies" (forthcoming 20I0) 4I George Washington International Law Review.

I7. For analysis of the classical European tradition, see e.g., David J. BEDERMAN, "The Classical Tradition in International Law: Grotius' De Jure Belli Ac Pacis" (I996) Io Emory International Law Review I at I9; Leo GROSS, “The Peace of Westphalia” in Leo GROSS, ed., International Law in the Twentieth Century (New York: Appleton-Century Crofts, I969), 25.

I8. R.P. ANAND, New States and International Law, 2nd ed. (Delhi: Hope India Publications, 2008).

I9. See e.g., Robert O. KEOHANE and Joseph S. NYE Jr., "Power and Interdependence in the Information Age" (I998) 77 Foreign Affairs 8I at 87 and 94. 
Analysis of some aspects of the norms of accountability and access to information, and to a lesser extent, participation, is detailed below.

\section{Accountability}

The ability to hold an institution, non-governmental organization, private sector corporate network, or informal coalition accountable for its actions is essential to legitimacy. In the kaleidoscopic world, accountability becomes more difficult, because there are many more actors to be held accountable, many more actors for them to be accountable to, and the means for doing so effectively may be more elusive. At the same time, accountability is more essential to prevent abuses in the international system.

Webster's dictionary defines accountable as "being obliged to account for one's actions, i.e. to give satisfactory reasons". ${ }^{2 \circ}$ Accountability can be distinguished from "responsibility", although in languages other than English, the two concepts may be joined and translated as "responsibility". An actor can be responsible for taking certain measures but not have to account for what is done, either to higher authorities, other actors, or those affected by the actions, and may not be subject to any sanctions or other measures of performance. Accountability adds an element of "process" into legitimacy.

Since the beginning of the twenty-first century, there have been growing concerns about the accountability of many kinds of actors in the international system: states and their governments, international organizations, including international financial institutions, private sector institutions, especially corporations and banks, nongovernmental organizations, and, increasingly, ad hoc coalitions. ${ }^{2 \mathrm{~T}}$ There are at least five questions associated with accountability. Who is accountable, to whom, for what, when, and how? While the questions appear simple, the responses are often layered and complex and vary with the particular institution or institutional context.

There are at least two fundamental approaches to accountability: top-down and bottom-up. ${ }^{22}$ The top-down approach is the traditional model. Those who are in charge hold those who work for them or report to them accountable for their actions or performance. The relationship is hierarchical. Most organizations are structured internally in this way. International institutions also work in this way, although they may as an institution be formally accountable to the states who are parties to the agreement establishing the institution. ${ }^{23}$

20. See Merriam-Webster Online Dictionary, online: Merriam-Webster Online Dictionary 〈http:// www.merriam-webster.com/dictionary/accountable $\rangle$. Webster's New International Dictionary of the English Language, unabridged, in I946, defined accountable as "answerable”, at I6.

2I. See e.g., Anne PETERS, Lucy KOECHLIN, Till FÖRSTER, and Gretta Fenner ZINKERNAGEL, eds., Non-State Actors as Standard Setters (Cambridge: Cambridge University Press, 2009); David HELD and Mathias KOENIG-ARCHIBUGI, eds., Global Governance and Public Accountability (Malden: Blackwell Publishing, 2005); World Bank Inspection Panel, Accountability at the World Bank: The Inspection Panel 10 Years on (Washington: The International Bank for Reconstruction and Development / The World Bank, 2003); Michael EDWARDS and David HUME, eds., Beyond the Magic Bullet: NGO Performance and Accountability in the Post-Cold War World (West Harford: Thomson-Shore, Inc., I996).

22. See Edith BROWN WEISS, "Bottom Up Accountability" (2007) 37 Environmental Policy and Law 259.

23. Some scholarship has suggested the distinction between internal and external accountability to differentiate between these different relationships in accountability: see e.g., Robert O. KEOHANE, "Accountability in World Politics" (2006) 29 Scandinavian Political Studies 75 at 79. 
In the bottom-up approach, institutions are responsible to those whom they serve or affect and affected peoples have ways to hold them accountable. As noted above, international organizations serve the states who established them, which is a more horizontal approach. Bottom-up accountability generally starts with those who are affected, normally parts of civil society. In democracies, governments are theoretically accountable to the citizens they serve. Corporations are accountable to their boards of directors and to their shareholders, and increasingly to the public. Many of those affected by the activities of corporations or other private companies are members of the general public. The Enron scandal in the United States affected not only the shareholders, but all those who suffered as result of the loss of pension funds, overpriced energy resources, etc. ${ }^{24}$ Similarly, after 2008 and 2009 , one can argue that investment banks should be accountable not only to stockholders but also to those who are directly affected by sudden declines in wealth and large bail-out packages. ${ }^{25}$ This also applies to the commercial banking sector.

For international institutions, the bottom-up approach means that the institutions are accountable not only to the states that established them but, significantly, to the communities, groups, and individuals they are intended to serve. This means that there need to be institutional mechanisms for those affected by the actions of international institutions to hold them accountable.

Within the last two decades, new means have developed to implement the bottom-up approach to accountability. These can be seen in the fields of economic development through the use of complaint procedures accessible by affected people, as in the World Bank Inspection Panel ${ }^{26}$ and other multilateral development bank and national mechanisms; ${ }^{27}$ in human rights through the right of individuals to complain

24. See Joseph A. CASTELLUCCIO III, "Sarbanes-Oxley and Small Business: Section 404 and the Case for a Small Business Exemption” (2005) 7I Brooklyn Law Review 429 at 449; see also The Enron Collapse: Impact on Investors and Financial Markets, Joint Hearing Before the Subcommittee on Capital Markets, Insurance, and other Government Sponsored Enterprises and the Subcommittee on Oversight and Investigations of the House Committee on Financial Services, I07th Congress of the United States (December 200I); The Effect of the Bankruptcy of Enron on the Functioning of Energy Markets, Hearing Before the Subcommittee on Energy and Air Quality of the House Committee on Energy and Commerce, I07th Congress of the United States (February 2002).

25. See generally Margaret BLAIR and Lynn A. STOUT, “A Team Production Theory of Corporate Law” (I999) 85 Virginia Law Review 247.

26. World Bank, World Bank Inspection Panel, Resolution No. IDA 93-6 (I993), online: The World Bank 〈http://www.inspectionpanel.org 〉. There have been two "Clarifications of Certain Aspects of the Resolution", in 1996 and in I999. The texts of the resolution and clarifications are available in the Annual Reports of the World Bank Inspection Panel, online: World Bank Annual Report 〈http://www.inspectionpanel.org >; see also Center for International Environmental Law, Introduction to the World Bank Inspection Panel, online: Center for International Environmental Law 〈http://www.ciel.org/Ifi/wbip.html〉.

27. Asian Development Bank, Review of the Inspection Function: Establishment of a New ADB Accountability Mechanism (2003), online: ADB Accountability Mechanism <http://www.adb.org/Documents/Policies/ ADB_Accountability_Mechanism/default.asp?p=policies $\rangle$; African Development Bank, African Development Fund, Board of Directors, Independent Review Mechanism, Res. B/BD/2004/9-F/BD/2004/7 (2004), online: African Development Bank Group Independent Review Mechanism <http://www.afdb.org/en/aboutus/structure/independent-review-mechanism/ $>$; European Bank for Reconstruction and Development [EBRD], The Independent Recourse Mechanism, BDS 03-33 (2003), online: EBRD 〈 http://www.ebrd.com/ about/integrity/irm/about/index.htm $\rangle$; EBRD, Project Complaint Mechanism, approved by the Board of Executive Directors, 6 May 2009, online: EBRD 〈http:/www.ebrd.com/oppor/ngo/am/PCM.pdf 〉; EBRD, Project Complaint Mechanism: Rules of Procedure, 6 May 2009, online: EBRD 〈http://www.ebrd.com/ about/integrity/irm/about/pcm.pdf $\rangle$; Inter-American Development Bank [IDB], The IDB Independent 
about human rights violations to international bodies; ${ }^{28}$ and in environmental protection through regional agreements that provide the rights of individuals and groups to complain about the lack of compliance with a convention ${ }^{29}$ or about the lack of national environmental law enforcement. ${ }^{3 \circ}$

There has been a rapid growth in complaints by individuals and groups about the failure of states and international institutions to comply with legal obligations. In one sense, the growth in complaints by individuals for violations of human rights, particularly in Europe, reinforces the assertion that international law in the twentieth century has been embedded in Western culture. However, these developments also point to something broader, which is trans-civilizational-namely, the empowerment of communities and individuals to hold authorities accountable for their actions.

\section{Access to information and participation}

Access to information, which is part of transparency, and public participation are important emerging norms in international law. They may contribute to the perceived legitimacy of international law in a kaleidoscopic world with its innumerable actors and shifting coalitions. In I992, the Rio Declaration on Environment and Development provided in Principle ro that:

Environmental issues are best handled with the participation of all concerned citizens, at the relevant level. At the national level, each individual shall have appropriate access to

Investigation Mechanism, Doc. IIM6-oo (2000), online: IDB Independent Investigation Mechanism 〈http:// www.iadb.org/aboutus/iii/independent_invest/independent_invest.cfm?language=English $\rangle$; IDB, Proposed Independent Consultation and Investigation Mechanism: Draft (2009); International Finance Corporation Compliance Advisor/Ombudsman, Operational Guidelines (2007), online: CAO Ombudsman <http:// www.cao-ombudsman.org/html-english/about.htm $\rangle$; Japan Bank for International Cooperation, Major Rules for Establishment of Examiner for Environmental Guidelines, (2009), online: Japan Bank for International Cooperation 〈http://www.jbic.go.jp/en/about/environment/guideline/disagree/ $\rangle$; Overseas Private Investment Corporation, Office of Accountability, online: Overseas Private Investment Corporation 〈http:// www.opic.gov/doingbusiness/accountability/index.asp $\rangle$; Export Development Canada, Resolutions Respecting the Compliance Officer for Export Development Canada (200I), online: Export Development Canada 〈http://www.edc.ca/english/compliance.htm $\rangle$.

28. Optional Protocol to the International Covenant on Civil and Political Rights, I6 December I966, 999 U.N.T.S. I7I, Can. T.S. I976 No. 47, 6 I.L.M. 368 (entered into force 23 March 1976); Convention on the Elimination of All Forms of Discrimination Against Women [CEDAW], I March I980, I249 U.N.T.S. I3 (entered into force 3 September I98I); and Optional Protocol to CEDAW, 6 October I999, GA Res. 54/4 (entered into force 22 December 2000); Convention Against Torture and Other Cruel, Inhuman or Degrading Treatment or Punishment, Io December I984, 1465 U.N.T.S. 85 (entered into force 26 June I 987); International Convention on the Elimination of All Forms of Racial Discrimination, 2I December I965, 660 U.N.T.S. I95 (entered into force 4 January I969); Convention for the Protection of Human Rights and Fundamental Freedoms, 4 November I950, 2 I3 U.N.T.S. 22 I, as amended by Protocol No. 11, I I May 1994 (entered into force I November I998); American Convention on Human Rights, 22 November I969, I I44 U.N.T.S.I23 (entered into force I 8 July I978).

29. Aarhus Convention on Access to Information, Public Participation in Decision-Making and Access to Justice in Environmental Matters, 25 June 1998, ECE/CEP/43, 216I U.N.T.S. 447 (entered into force 30 October 200I) [Åarhus Convention].

30. North American Agreement on Environmental Cooperation, I4 September I993, 32 I.L.M. I480 (entered into force I January I994). As of 9 December 2009, the North American Commission on Environmental Cooperation listed seventy-two submissions under the complaint procedure, which included several repeat or corrected submissions. See Commission for Environmental Cooperation, Citizen Submissions on Enforcement Matters online: Registry of Citizen Submissions, online: Commission for Environmental Cooperation 〈http://www.cec.org/Page.asp?PageID $=75 \mathrm{I} \&$ SiteNodeID $=$ 250\&BL_ExpandID $=99>$. 
information concerning the environment that is held by public authorities ... and the opportunity to participate in decision-making processes. States shall facilitate and encourage public awareness and participation by making information widely available. ${ }^{3}$

Since I992, some international agreements and other legal instruments provide for public access to information, transparency, and the participation of people in decisions affecting them..$^{32}$ These provisions empower local communities, particularly those that are impoverished. They help to make economic development, for example, responsive to the needs and desires of the local community and consistent with the cultural traditions of the community.

Access to information is especially critical to enable governments and all actors to adapt to changing scientific understanding of global problems, such as climate change, or to address new global or regional problems that suddenly emerge, such as epidemics or financial crises. International legal instruments in turn need to be sufficiently flexible for relevant actors to respond and adapt in a timely manner to new information and scientific understandings.

While access to information is an essential component of bottom-up empowerment, there is a danger that the information can also be used to help actors with malevolent intentions. The same information that lets communities know what is happening within institutions and holds management and staff accountable can also be used for illicit purposes or private gain. Yet to the extent that communities rely on voluntary actions to be taken in the community interest, whether local or global, access to information, transparency, and participation are essential elements in international law.

Within institutions, however, there are also important questions regarding appropriate limits on access to information. There is a line beyond which unfettered transparency and access to information may impede forthright exchanges. At the point that authorities decline to deliberate issues fully or document decisions for fear of transparency, decisions will suffer. The aversion to providing written records is particularly harmful, for it thwarts historical learning, hides scurrilous and unfounded assumptions, hinders post-evaluations, and leads to a breakdown of trust within an institution. Thus, while promoting transparency may be paramount, it is also important to delineate clearly the rationale and guideline for declining to make certain information available. Holding institutions accountable for complying with appropriate norms of transparency promotes trust by those affected by the actions of the institution.

Advances in information technology enable us to generate and store vast amounts of information. In this sense, information technology enhances the ability of individuals, groups, and communities to be informed, to develop common awareness, and to participate in decision-making. But it also makes it easy for people to be exposed only to information that reflects their preconceptions and points of view, and it may be difficult to persuade them to consider other kinds. Most importantly, while information is

31. Rio Declaration on Environment and Development, UNCED, UN Doc. A/CONF.I 5I/26/Rev.I, Vol.I (1992).

32. E.g., Åarhus Convention, supra note 29. 
voluminous, it has become more difficult to know whether the information is authentic and correct. One of the significant challenges for international law is to ensure that there are well-established reputable electronic sites that provide accurate information on existing sources of international law, implementation in national systems, and non-binding legal instruments by actors other than states.

\section{INTERNATIONAL LAW AS A STABILIZING FORCE FOR ADDRESSING COMMON PROBLEMS}

As noted at the outset, global problems can affect all communities and people, both now and in the future. They arise in the context of globalization, fragmentation, and bottomup empowerment and constantly changing informal groupings, ad hoc coalitions, and innumerable individual initiatives. In a kaleidoscopic world, there are at least three generic approaches to addressing these problems, each with a certain validity, and each invoking international law. These are: (a) reliance on states in exercising national sovereignty over their territories and areas under their jurisdiction; (b) international regulation by states, international institutions, or formal transnational networks; and (c) voluntary co-operative actions, especially by civil society and other non-public actors. The relevant legal instruments include binding international agreements, non-binding legal instruments, soft law guidelines or best practices, and informal "rules of the road". Markets have also been major conveyors of information and instruments that affect both the development of the problems and the solutions to them.

The traditional approach relies on states and their exercise of national sovereignty. Historically, international law has governed the relations between states. Just as the number of other kinds of actors has grown, the number of states has also increased in recent decades. When the United Nations was formed in I945, fifty-one states joined the agreement. ${ }^{33}$ In 2009, I 92 states were members of the United Nations, almost three-quarters of which had acquired independence within the previous sixty years. But while there are now many states that can negotiate binding agreements, many global problems seem to require rapid actions by smaller groups of countries and officials within countries or by elements in the private sector. They may need non-binding legal instruments, at least initially. The need for rapid movement to address pressing global problems arguably dilutes the powers of those states that lack capacity to address these rapid-fire challenges from globalization. Many of these states achieved their independence within recent decades. Just as they have achieved independence and found their place in the international community, their power has been diminished.

Some scholars have written persuasively about the demise of national sovereignty. ${ }^{34}$ While states still retain important powers in the area of national security, their effective

33. See United Nations, History of the UN, online: United Nations 〈http://www.un.org/aboutun/history.htm 〉. A list of the original signatories can be found at $\langle$ http://treaties.un.org/Pages/ViewDetails.aspx? $\operatorname{src}=$ TREATY\&id $=308$ \& chapter $=\mathrm{I}$ \&lang $=\mathrm{en}>$.

34. See e.g., Louis HENKIN, "The Mythology of Sovereignty" in Ronald S.J. MACDONALD, ed., Essays in Honour of Wang Tieya (Dordrecht: Martinus Nijhoff Publishers, I993), 35I; Martti KOSKENNIEMI, 
authority in other areas is visibly diminished or seriously challenged. Even so, states will continue to be important actors in many respects in the kaleidoscopic world.

Increasingly, there is a move towards greater international regulation, not only of the conduct of states but also of non-state actors, including those in international commercial and financial markets, and of individuals. We can anticipate that, in the kaleidoscopic world, new international institutions will arise or existing ones will be revised to tackle more diverse problems at multiple levels. In this scenario, binding international agreements among states will increase, as will international legal instruments that regulate the behaviour of non-state actors. International regulation can facilitate predictability about the actions states and other actors will take, level the playing field, and provide stability to the system for addressing issues.

One of the most significant aspects of international regulation is that smaller groups of states are creating informal international institutions and non-binding legal instruments to address global problems. In response to the recent financial crisis, for example, the Group of Twenty has established the Financial Stability Board, which is not a formal international organization and was not established by a binding international agreement, but has significant powers to address global financial problems. ${ }^{35}$ Similar trends are visible in other areas of global concern, such as the control of money laundering ${ }^{36}$ and, in some areas, piracy. ${ }^{37}$

In a kaleidoscopic world, many of the actions we need to take to manage our increasingly complex system will be widely dispersed, involve shifting coalitions of actors, and will change quickly. In this context, it may be increasingly important to focus on the voluntary coming together of people to tackle common problems, whether from self-interest or community awareness. This approach focuses on voluntary international co-operation, which may consist of many local actions. ${ }^{38}$ The approach depends upon the development of a consensus regarding values to pursue and of a shared concern about common problems that affect the wellbeing of all peoples and the Earth. It is effective when participants are joined together in facing common problems both now and in the future and can effectively monitor each other's actions.

The incentives for voluntary actions are that they will achieve positive benefits that no one state, group, or coalition can achieve individually or that they will avoid an ever-worsening situation in which all suffer. It requires that actors view themselves

\footnotetext{
"The Future of Statehood" (I99I) 32 Harvard International Law Journal 397; John JACKSON, Sovereignty, the WTO and Changing Fundamentals of International Law (Cambridge: Cambridge University Press, 2006).

35. Group of Twenty, London Summit-Leaders' Statement (2 April 2009) at 3, online: Group of 20 $\langle$ http://www.g20.org/Documents/g20_communique_020409.pdf〉; Elena MOYA, "Financial Stability Board: How It Will Work” Guardian (4 April 2009).

36. Beth SIMMONS, "International Efforts Against Money Laundering” in Dinah SHELTON, ed., Compliance and Commitment: The Role of Non-Binding Norms in the International System (Oxford: Oxford University Press, 2000) 244 at 245 .

37. US Congressional Research Service, Piracy off the Horn of Africa (2009) at I8-I9.

38. See e.g., Elinor OSTROM, Roy GARDNEER, and James WALKER, Rules, Games, and Common-Pool Resources (Ann Arbor: University of Michigan Press, I994); Elinor OSTROM, Governing the Commons: The Evolution of Institutions for Collective Action (Cambridge: Cambridge University Press, I990).
} 
as joined together inseparably for the long term, so that actions today that may benefit a few at the expense of the many will have harmful consequences in the future for those taking them or preclude benefits for all in the future.

The voluntary approach is particularly important with the emergence of bottomup empowerment. The approach builds upon public participation and depends upon access to information, transparency (or sunshine) about actions, and compliance with binding and non-binding norms, and a shared sense that the norms and legal instruments are fair and legitimate. Non-binding legal instruments and informal agreements are common.

The international legal system in this century will include all three approaches, with the latter two gaining in importance. International institutions, linked to these approaches, will likely grow in importance, whether they be public or private, formal or informal.

In the twenty-first century, international law is needed more than ever to promote equity, human dignity, peace and security, and predictability in the international system. These are the traditional functions of international law. In the emerging kaleidoscopic world, law is particularly essential to promoting stability. Forging effective links between the formalism of international law and institutions and the trans-civilizational reality will be difficult but essential. The challenge for all peoples is to ensure that international law reflects shared values that bind people together and that it provides processes that all regard as fair and as ensuring accountability by states, non-state actors, and the myriad of other actors, especially individuals.

We could move towards a system in which states retain significant powers, international institutions of all kinds increase in number and power, international regulation of all actors and transactions grows, and, importantly, voluntary co-operation from bottom-up empowerment emerges to address common threats and achieve common aims. Or we could face a regular series of crises, in which the entire system threatens to break down, and widespread disorders threaten to break out at many levels. In the latter case, it is not clear that such breakdowns could be contained. Even if the incentives to contain them are present, the necessary trust in the system may not be. The practical challenges are immense, particularly because the constellations in the kaleidoscopic world are constantly changing. The future of international law in this complex context could be usefully explored in case-studies such as climate change, health threats, financial markets, and effective poverty reduction. 
Reproduced with permission of the copyright owner. Further reproduction prohibited without permission. 